\title{
Perspective asupra textului și discursului religios, volum îngrijit de Ioan Milică, Emanuel Gafton și Sorin Guia, Editura Universităţii „Alexandru Ioan Cuza”, Iași, 2013, 346 p.
}

\author{
Enikő Pál ${ }^{*}$ \\ Facultatea de Științe Economice și Umaniste, Universitatea Sapientia, Piața Libertății 1, 530104 Miercurea Ciuc, România
}

Apariția volumului Perspective asupra textului și discursului religios, publicat în 2013, la Editura Universităţii „Alexandru Ioan Cuza” din Iași, a constituit un eveniment însemnat pentru comunitatea științifică reunită sub egida Conferinței Naţionale „Text și discurs religios”. Încă de la momentul inițierii, această manifestare ştiințifică a antrenat (şi antrenează în continuare) oameni de știinţă de la diverse centre universitare și de cultură ale țării, constituind un spațiu al dezbaterilor deschis tuturor celor „preocupaţi cu studierea problemelor legate de textul și de discursul religios, privite în sincronie și în diacronie, din perspectivă lingvistică, retorică, literară, teologică, filosofică, istorică”. Organizată din an în an, Conferința a căpătat din ce în ce mai mare vigoare și s-a consolidat, instituind o adevărată tradiție menținută pînă în prezent.

Volumul de față, îngrijit de Ioan Milică, Emanuel Gafton și Sorin Guia, se înscrie în cadrul colecției „Text și discurs religios”, considerată publicație periodică anuală. Întocmirea acestuia a fost stimulat de un moment aniversar-celebrarea desfășurării reușite a cinci ediții ale Conferinței (2008-2012) și a editării celor cinci volume dedicate acesteia (2009-2013). În acest fel, volumul Perspective... este menit să ofere un omagiu participanților Conferinței și întregii comunități științifice preocupate de chestiunile dezbătute la aceasta, așa cum mărturisesc editorii în Cuvînt înainte (p. 8).

Volumul aniversar reunește studiile publicate în cele cinci volume anterioare ale Conferinței care abordează textul și discursul religios din diverse perspective. Cele 25 de articole incluse în prezentul volum sînt semnate de oameni de știință consacrați şi/sau de cercetători avizați, în curs de afirmare. Felul în care au procedat editorii la întocmirea volumului, cum au selectat lucrările, după ce criterii, este indicat în Cuvînt înainte. Astfel, „selecția aparține editorilor şi a avut în vedere cuprinderea majorităţii chestiunilor dezbătute cu interes în cadrul Conferinței, precum și felul în care, în general, participanții s-au raportat la diferitele modalități de prezentare a respectivelor chestiuni" (p. 8).

Comunicările selectate spre (re)editare se înscriu in sfera biblisticii, a traductologiei, a retoricii, a pragmaticii sau a stilisticii, dar ating şi domenii precum istoria, filosofia sau arta. De altminteri, studiile volumului ar putea fi grupate în cinci secțiuni inegale: Cuvinte de intimpinare; Istoria cuvintului; Traducerea textului sacru; Retorica discursului religios și Literatura și sacrul ${ }^{1}$. Prima secțiune cuprinde comunicări de întîmpinare rostite la diferite ediții premergătoare ale Conferinței. Cea de-a doua a constituit o secțiune de sine stătătoare a primei ediții a Conferinței la care, ulterior, s-a renunțat, ea fiind înglobată în alte sfere tematice. În sfîrșit, ultimele trei secțiuni reprezintă secțiuni constante ale Conferinței, ele circumscriind, în esență, filoanele tematice ale acesteia ${ }^{2}$.

Volumul omagial reia trei Cuvinte de intîmpinare din edițiile anterioare ale publicației „Text și discurs religios": Ethos, Pathos și Logos in textul predicii, comunicare semnată de Rodica Zafiu (din nr. 2/2010), în care se trec în revistă mijloacele de realizare a componentelor persuasiunii din predicile contemporane; Text și imagine în vechea civilizație a românilor, de Răzvan Theodorescu (din nr. 3/2011), în care se insistă asupra paralelismului cultural fundamental ce există între a scrie și a vedea, respectiv a etapelor, în

*Adresă de corespondență: enikopaldr@gmail.com.

${ }^{1}$ Această structurare urmează modelul de organizare a studiilor din volumele 2008-2012. Spre deosebire de acestea, în volumul aniversar, studiile urmează unele după altele, fără alte segmentări.

${ }^{2}$ La sfîrșitul fiecărui articol se indică locul de unde acesta a fost reprodus, menționîndu-se numărul volumului, anul apariției și paginile. Unele dintre articolele incluse în acest volum, inițial, au apărut în limbi străine (în franceză—vezi studiile semnate de A. Chirilă \& G. B. T,âra, de S. Ispas, de Gh. Chivu—sau în engleză—cele scrise de Al. Mihăilă și de I. Milică). 
vechea civilizație a românilor, de raportare a vizualității la text; și Scrisul religios, componentă definitorie a culturii vechi româneşti, de Gheorghe Chivu (din nr. 4/2012), în care autorul arată felul în care scrisul religios s-a constituit într-o variantă paralelă a scrisului literar, un exemplu de continuitate și de stabilitate, un remarcabil izvor de inspirație, un rezervor de mijloace stilistice și un model retoric apreciat adesea de scriitorii cultivați.

Din secțiunea Istoria cuvîntului din primul volum al Conferinței au fost alese cu grijă de către editori și reproduse patru studii: Adevărul, între cuvîntul biblic și cuvîntul poetic, semnat de regretatul Dumitru Irimia; Discursul religios, model și normă de exprimare îngrijită în epoca veche, de Vasile D. Țâra; Eshatologie și secularizare in straie postmoderne, de Gheorghe Manolache și Discursul profetic intre voința lui Dumnezeu și voia poporului, de Lucian Farcaş. Aceste scrieri sînt de o deosebită valoare, ele oferind informații competente care țin de domeniile lexicologiei, semioticii și filosofiei limbajului, al istoriei limbii și stilisticii.

În secțiunea Traducerea textului sacru se pot încadra cele mai multe studii selectate spre republicare, nouă la număr, după cum urmează: Finalitatea textelor slavo-române intercalate din Evul Mediu românesc, semnat de Dragoș Moldovanu; Biblia de la 1688. Aspecte ale traducerii, de Alexandru Gafton; Două ipostaze ale libertății traducătorului biblic: sinonimizare și pia interpretatio. Studiu de caz: vechile traduceri românești ale cărților 1 și 2 Regi (Ms. 45 și Biblia de la 1688), de Adrian Muraru; Opțiuni și constrîngeri lexico-semantice în traducerile textului biblic, de Adina Chirilă și George Bogdan Țâra; Lecţiuni controversate in Sfinta Scriptură, de Dionisie Constantin Pîrvuloiu; Aspecte ale traducerii la Dosoftei, de Mădălina Andronic-Ungureanu; Elemente biblice in inscripțiile funerare în limba latină din țările române (1300-1800), de Doina Filimon Doroftei; Retorica judecății divine în Scriptura ebraică, de Cătălin Vatamanu și „Străinul... va fi pentru voi ca și băștinașul” (Lev. 19:34). Includere și excludere din comunitatea religioasă în Iehud de Alexandru Mihăilă. Dincolo de faptul că, în aceste lucrări, se dezbat aspecte teoretice de traductologie, semnificativ este și faptul că ele oferă un material lingvistic extrem de bogat și de util cu privire la traducerea textului biblic. Exemplificările autorilor, alese cu mare grijă și pricepere, evidențiază unele înțelesuri mai nuanțate ale Sfintei
Scripturi, înlesnind înțelegerea acesteia și, în același timp, oferind (şi) modele de interpretare a ei.

Secțiunea Retorica discursului religios din volumele anterioare este și ea prezentă cu o pondere deosebită, în volumul de față fiind reproduse șapte studii aparținînd acestei sfere de preocupări: Despre pregătirea în vederea lecturii unei pagini de teologie, semnat de Ștefan Afloroaei; Retorica elogiului in „Didabiile" lui Antim Ivireanul, de Maria Cătănescu; Retorica blamului în predica lui Antim Ivireanul, de Laura Bădescu; Coerența discursului religios in „Didabiile" lui Antim Ivireanul, de Constantin Frâncu; Arta dialogului in Prefețele Mitropolitului Veniamin Costachi, de Sorin Guia; Modele retorice ale invocației in contextul religiozității populare, de Ioana Repciuc și Imaginarul creștin în denumirile populare românești de plante, de Ioan Milică. Comunicările grupate aici valorifică o gamă largă de material textual privit prin prisma unei mari varietăți a mijloacelor retorice întrebuinţate.

Cel mai puțin reprezentată în volum este tematica Literatura și sacrul, din această secțiune fiind alese spre reeditare numai două articole: Ipostaze ale vegetalului în spiritualitatea românească, semnat de Sabina Ispas și Reprezentarea sacrului în folclorul religios românesc: influența discutabilă a dualismului oriental, de Lucia Afloroaei. Acestea se remarcă însă prin calitatea lor desăvîrșită, prin pertinența și finețea observațiilor.

Luat în ansamblu, meritele acestui volum sînt multiple. În această ediție sînt republicate, laolaltă, unele dintre cele mai valoroase scrieri filologice, lingvistice, de teologie etc. Prin selecția operată de către editori, foarte utilă și bine întocmită și care a presupus o cercetare laborioasă, ni se dezvăluie un univers întrețesut de sacru și de profan, o lume, poate, mai puțin cunoscută de către contemporaneitate.

Fiind pătrunși de o spiritualitate profundă, textul şi discursul religios constituie o lectură dificilă care ridică numeroase probleme în fața cititorului modern. Astfel, volumul Perspective... înlesnește căile de acces la aceste texte și, în același timp, el este menit a atrage atenția atît specialiștilor, cît și unei sfere mai largi de cititori, asupra importanței literaturii religioase vechi, dar și asupra limbajului bisericesc actual. La acest lucru servesc și bibliografiile selective care însoțesc fiecare articol în parte și care încurajează și orientează cititorul către lecturi suplimentare.

Astfel, prin publicarea acestui volum se sublini- 
ază totodată şi însemnătatea pe care tematica parcursă o are în planul exegezei contemporane. $\mathrm{Cu}$ alte cuvinte, eleganta ediție reafirmă necesitatea unor reuniuni și publicații științifice (anuale) avînd o astfel de preocupare precum cea propusă de Conferința
Națională „Text și discurs religios”.

Lucrările cuprinse în volumul Perspective... sînt accesibile atît prin intermediul acestui volum, cît și on-line, pe site-ul www.cntdr.ro. 